DOI: https://doi.org/10.24127/ajpm.v10i4.4096

\title{
“CABRI 3D SOFTWARE" TECHNOLOGY: STUDENTS' PROBLEM SOLVING SKILLS WITH PROBLEM BASED INSTRUCTION MODEL APPROACH
}

\author{
Almira Amir ${ }^{1 *}$, Ihamuddin ${ }^{2}$ \\ ${ }^{1,2}$ Institut Agama Islam Negeri (IAIN) Padangsidimpuan, Indonesia \\ E-mail : almiraamir1973@gmail.com ${ }^{1 *}$
}

Received 06 August 2021; Received in revised form 12 September 2021; Accepted 15 December 2021

\begin{abstract}
Nowadays, 21st-century learning requires students to develop higher-order thinking skills, one of which is the ability to solve a problem. The purpose of this study was to analyze the effect of using the Problem Based Instruction model with the help of Cabri 3D Software on students' problem-solving skills. The method used in this research is an experimental method with a quantitative approach. While the design in this study used a pretest-posttest control group design, using an instrument in the form of a test. The target subjects in this study were students of class VIII MTs Muhammadiyah - 8 Siabu. Meanwhile, the data analysis technique used is inferential statistics in the form of a t-test. The results showed that the calculation of the $t$-test obtained $t_{\text {count }}=2,708$ and continued by looking at the table based on the sample size of 48 people, (the experimental class consisted of 23 people while the control class consisted of 25 people) at a significant level of $5 \%$ found $t_{\text {table }}=2,012$ then $t_{\text {count }}(2.708)>t_{\text {table }}(2.012)$, it means that $t$ is in the reception area. So it can be concluded that there is a significant effect of the Problem Based Instruction model with the help of Cabri 3D software on students' problem-solving abilities on the subject of spatial construction. The research implication is that the application of technology is needed to design innovative and credible thinking and student experiences in responding to the challenges of the 21 st century, especially in problem-solving skills.
\end{abstract}

Keywords: Cabri 3D Software; Problem-based instruction model; Problem-solving skills.

\begin{abstract}
Abstrak
Dewasa ini, pembelajaran abad 21 menuntut siswa dalam untuk mengembangkan kemampuan dalam berpikir tingkat tinggi salah satunya seperti kemampuan dalam memecahkan sebuah masalah. Tujuan dari penelitian ini untuk menganalisis pengaruh penggunaan model Problem Based Instruction berbantuan Software Cabri 3D terhadap kemampuan pemecahan masalah siswa. Metode yang digunakan dalam penelitian ini adalah metode eksperimen dengan pendekatan kuantitatif. Sementara desain dalam penelitian ini menggunakan pretest-posttest control group design, dengan menggunakan instrumen berupa tes. Sasaran subyek pada penelitian ini merupakan siswa kelas VIII MTs Muhammadiyah - 8 Siabu. Adapun, teknik analisis data yang digunakan adalah statistik inferensial berupa uji-t. Hasil penelitian menunjukkan bahwa perhitungan uji-t yang diperoleh thitung = 2,708 dan dilanjutkan dengan melihat pada tabel berdasarkan jumlah sampel 48 orang, (kelas eksperimen terdiri 23 orang sedangkan kelas kontrol terdiri 25 orang) pada taraf signifikannya $5 \%$ ditemukan $t_{\text {tabel }}=$ 2,012 maka $t$ hitung $(2,708)>t_{\text {tabel }}$ (2,012), artinya $t$ berada di daerah penerimaan. Sehingga dapat disimpulkan adanya pengaruh signifikan model Problem Based Instruction berbantuan Software Cabri $3 D$ terhadap kemampuan pemecahan masalah siswa pada pokok bahasan bangun ruang. Implikasi penelitian yakni penerapan teknologi dibutuhkan untuk mendesain pemikiran dan pengalaman siswa yang inovatif dan berkredibel dalam menjawab tantangan abad 21 ini khususnya dalam keterampilan pemecahan masalah.
\end{abstract}

Kata kunci: Keterampilan memecahkan masalah; Model instruksi berbasis masalah; Software Cabri 3D

This is an open access article under the Creative Commons Attribution 4.0 International License 
DOI: https://doi.org/10.24127/ajpm.v10i4.4096

\section{PENDAHULUAN}

Learning activities aim to improve students' skills and competencies in achieving competency of attitudes, knowledge, and skills (Bao et al., 2018; Yuberti et al., 2019). It is known that the 21 st century goal of those countries is to develop individuals who are physically, mentally, emotionally and in a healthy social aspect, live in harmony with their environment, are with their family and social environment, have skills in problem solving, are creative, entrepreneurial, productive, dynamic and confident. Of all these characteristics, it becomes a universal value, and the most important thing is to have problem solving skills (Akpinar, 2020). It is in line with the opinion of Tösten et al. (2017) which says that one of the important skills that students are expected to acquire is problem solving skills. Among the components of skills expressed as 21st century skills, problem solving skills become one of important components.

In implementing the 2013 Curriculum in Indonesia, problem-based learning must be done recommending teaching mathematical problem solving. However, students experience difficulties when they learn mathematical problem solving using problem-based learning (Sarjoko \& Demitra, 2018). The problems most often faced by students are related to mathematics. Behavioral mathematics related to perceptual problem solving skills, contained in programs ranging from preschool education to higher education (Yavuz \& Atar, 2020).

Problem solving skills have a central position in mathematics education. Mathematical problem solving skills are higher order thinking skills (Sarjoko \& Demitra, 2018). Problem solving based learning model has steps with clear problems to solve. The steps are looking for data or information that can be used to resolve problems, creating hypotheses for problems, testing hypotheses, and drawing conclusions (Orzechowski et al., 2017; Scherer \& Gustafsson, 2015)

Carpenter \& Moser (2020) argues that the process applied in problem solving depends on the child's basic knowledge gained. The child's wealth of knowledge facilitates the problemsolving process. Problem solving is a process that can be learned, and individuals can be helped through education to develop their problemsolving skills to overcome the difficulties they face. Therefore, the skills of teachers in solving classroom problems must be developed because teachers must provide the best solutions to problems that occur in every condition they face in the education system (Özgenel, 2018). Given that, this is accompanied by the development of the times in this 21 st century learning, teachers as facilitators in developing student knowledge in class should have skills in designing activities using technology to improve students' problem solving skills in class.

The National Council of Teachers of Mathematics states that problem solving is a necessary part of completing Mathematics learning. It means that to improve creativity, logic, criticism, and systematic thinking, students must master a series of problem-solving skills in Mathematics. Skills in solving a problem can also provide opportunities for students in particular to apply content knowledge in the fields of numbers and operations, algebra, geometry, measurement, and data analysis and probability (AlMutawah et al., 2019). Meanwhile, Alrahlah, (2016)considers that problem 
solving skills are a process that starts from the time when a student faces a problem until the end of the process when the problem is resolved.

Problem solving is essentially the basic skills needed for today's learners. Due to changes in professional standards, new demands and changes in learning and educational theories so that the education system revises the curriculum to include a learning environment that provides learners to use higher order thinking skills, especially problem solving skills Kozikoğlu, (2019). Meanwhile, some experts Ibrahim et al. (2019) argue that problem solving is an essential skill that influences all actions of life, from simple to complex. It leads the individual to find solutions to problems by applying previous acquired experiences.

Individuals who already have skills in solving problems will grow as confident individuals to individuals who can think creatively and independently YAZGAN, (2021). The situation in solving this problem also requires students to connect all the knowledge they have about the concepts, procedures, reasoning, and communication skills that are implemented to solve the problems at (Al-Mutawah et al., 2019).

Problem solving skills are often used in mathematics, this approach to problem solving is usually related to the mathematical process, application of concepts, physical and verbal relationships, as well as graphs and diagrammatic representations used by students in solving problems in the learning process in the classroom Yuliati et al., (2018).

One of the mathematics learning models used to improve students' problem-solving skills is the Problem
Based Instruction (PBI) model. The PBI model is one of the models that is often used to develop students' thinking in solving math problems in class. Zulkardi et al., (2020) revealed that the PBI learning model is one model that has advantages such as students being able to be actively involved in learning activities, students being trained to be independent and work together with others.

The Problem Based Instruction model is a way of learning where learning can encourage a deeper understanding of the material presented and this model is also problem-oriented where students not only gain knowledge when learning, but also experience how they use their knowledge to solve problems (Muah, 2016). The Problem Based Instruction model is a learning model based on constructivist understanding that accommodates student involvement in authentic learning and problem solving (Fitra et al., 2016). Problem Based Instruction (PBI) is one of the various learning models that teachers can use in activating students in learning (Amiluddin \& Sugiman, 2016). This Problem Based Instruction model begins by presenting real and meaningful life problems, then students are given the opportunity to conduct investigations, both inside and outside the classroom. Students are given the opportunity to learn to develop their potential through an activity to search for, solve and find a temporary concept or idea. Students act actively in dealing with and solving problems, and draw conclusions through the process of thinking scientifically, critically, logically, and systematically (Marnita et al., 2020).

One of the learning models based on constructivism theory and focusing 
students in learning is the Problem Based Instruction (PBI) model. PBI is a learning model based on many problems that require authentic inquiry, namely investigations that require real solutions to real and meaningful problems so that students can investigate and find their own solutions (Halim et al., 2021). The problem based instruction learning model of students is presented with unclear problems so that students can collaborate with other students to solve problems given by the teacher. The teacher acts as a facilitator to guide students in solving problems either individually or in discussion of the learning to focus on learning there is a learning process (Nariman \& Chrispeels, 2016).

The Problem Based Instruction model has five special characteristics, namely: a) Asking questions or problems. The problems presented are authentic real-life situations that avoid simple answers and provide multiple solutions. b) Focus on interdisciplinary. Although PBI is centered on one subject, the problem under study must be real so that in solving it students examine the problem from many subjects (if possible). c) Authentic questions. PBI requires students to conduct authentic investigations to find solutions to real problems. d) Produce products or works and display them. This Problem Based Instruction model requires students to produce certain products in the form of real works that explain or represent the forms of problem solving they find. e) Collaboration. Working together provides motivation to continue to engage in complex tasks and increases opportunities to share inquiry and dialogue and develop students' thinking skills. However, behind the advantages of this model in stimulating students to solve problems, the disadvantage of this PBI model is that it requires teachers to make lesson plans that are more mature and take a long time. In addition, students are only fixated on the instructions and problems given and are not accustomed to being given different instructions or problems (Nariman \& Chrispeels, 2016).

Currently, many computer programs have been improved to assist teachers and students in mathematics learning and teaching process. Some of them are Cabri 3D, Geogebra, Carmetal, Bagatrix, Wingeom, Sketchpad Geometer, Algebrator, Lindo, Graphmatic, and Cabri Geometry II (Lebamovski \& Gospodinov, 2019). Vallo \& Zahorska, (2017) very beneficial software for teaching and learning 3-dimensional geometry. The dynamic nature of digital diagrams is formed by providing useful assistance to assist learners in developing geometric concepts.

The use of 3D modeling and animation, being actively involved in education provides teachers with new tools to help students more easily perceive learning materials, increase their motivation, and help accelerate the learning of large amounts of knowledge (Lebamovski \& Gospodinov, 2019). In essence, the main purpose of using 3D technology to realize real models through computers. There are opportunities to apply 3D technology in mathematics (Lebamovski \& Gospodinov, 2019). One of the software applications made in teaching mathematics learning in the classroom is using 3D technology, this allows students to make observations, investigations, and discoveries on their own depending on the geometric objects being studied. This makes the learning process more interesting, motivating, 
improving quality and effectiveness (Lebamovski \& Gospodinov, 2019)

Given this, one of the 3D technologies that is often used in learning mathematics is CABRI 3D Software. Cabri 3D software is potentially very useful software for learning and teaching 3D geometry (Nurjanah et al., 2020). Cabri 3D is a potentially important tool for the development of solid geometry visual teaching (De Vita et al., 2018)

This Cabri 3D software can also be a useful tool for teaching spatial analytic geometry and prospective mathematics accepted by teachers (Adelabu et al., 2019). Cabri 3D is also a revolutionary piece of software that has the capacity to bring this important aspect of mathematics to life in a visually motivating way. Although the basic tools are relatively easy to master, the art is choosing tools and strategies to solve problems and this will be a new experience for most teachers (Adelabu et al., 2019)).

Among dynamic geometry software products, Cabri is probably the most researched product. Cabri Geometry is the first dynamic geometry software, and like other dynamic geometry software, is a micro world that allows exploration of multiple ways to solve a problem and discovery of concepts and relationships. The 3D version of Cabri can facilitate, in particular, the teaching of three-dimensional geometric concepts (Yuliardi et al., 2021).

Cabri 3D software also allows users to build and manipulate solid geometric objects in three dimensions through a $2 \mathrm{D}$ interface. By using Cabri 3D, threedimensional objects such as prisms, pyramids, cylinders and conical cans are constructed, rotated and viewed from certain aspects on the screen and prisms can be opened on the screen. The transformation offered by Cabri 3D is also a tool that can be used to build complex 3D objects (Mammana, 2019). So that in this research, the use of Cabri 3D software was carried out using a mathematical learning model such as Problem Based Instruction.

Given that it connects students' abilities in solving problems, problembased instruction models can be used when learning in class. Meanwhile, the technology used to carry out the implementation is using Cabri 3D software, because this software is one of the software that is often used in solving mathematical problems in the mathematics learning process, especially in geometry material. Meanwhile, previous research that has been carried out such as Maharani \& Laelasari, (2017) in his research shows that there is a significant influence between the use of problem-based learning models on student learning activities on the subject matter of mathematical logic for class $\mathrm{X}$ students of SMA Negeri 1 Sayurmatinggi. In line with Novianti et al., (2020), it also shows that there is a significant effect on problem-solving abilities using the Problem Based Instruction model.

Supported by Rahma, (2019) with the results of his research that there is a significant difference in mathematical problem solving abilities between students who are taught through the Problem Based Instruction model and students who are taught conventionally. Based on the results of previous research, there is no experimental test on the use of Cabri 3D software to determine students' ability to solve mathematical problems in class. This is what makes the gap in this research. Meanwhile, the purpose of this study was to determine and analyze the effect of the Problem Based Instruction Model 
on students' ability to solve problems through the help of Cabri 3D software.

\section{METHOD}

\section{Research sites}

The location in this study was carried out in one of the areas in Mandailing Natal Regency, North Sumatra, namely MTs Muhammadiyah 8 Siabu which was held from September 25, 2020 to November 24, 2020. The reason behind determining the location for an experimental act was related to the absence of experimental research. at the school, especially in the implementation of the use of CABRI 3D software by using the Problem Based Instruction Model approach to improve students' ability to solve problems.

\section{Participants}

Participants in this experiment were students in class VIII with a total of 48 students, with details of the experimental class as many as 23 students and the control class as many as 25 students. In this study, researchers also used a non-probability sampling design with the type of convenience sampling. Convenience Sampling type is a sampling technique based on availability and ease of obtaining it. The sample found by the researcher is willing to be used as a sample so it is not random.

\section{Research design}

This follow-up research uses experimental research with a quantitative approach. Quantitative research requires researchers to explain how one variable affects other variables (Creswell, 2012). This study describes the effect of using Cabri 3D software with a Problem Based Instruction model approach on students' problem solving abilities. Meanwhile, the pretest-posttest control group design research is described in Table 1 as follows:

Table 1. Quasi Experimental Research Design

\begin{tabular}{cccc}
\hline Class & $\begin{array}{c}\text { Pre } \\
\text { Test }\end{array}$ & Treatment & Post Test \\
\hline Experiment & $\mathrm{Q} 1$ & $\mathrm{X}$ & $\mathrm{Q} 3$ \\
\hline Control & $\mathrm{Q} 2$ & - & $\mathrm{Q} 4$ \\
\hline
\end{tabular}

Source: Sukmadinata (2005)

In this experimental follow-up, the experimental class was treated using Cabri 3D software with a Problem Based Instruction model approach, while the control class was not treated with a Problem Based Instruction model approach through the help of Cabri 3D software to determine and analyze students' abilities in solve problems in learning mathematics.

\section{Data Collection Technique}

The data collection technique in this study used test techniques as the primary data source and documentation techniques as a secondary data source. This test data collection technique was used to collect data in the form of student learning outcomes before and after the treatment using a problem based instruction model using Cabri 3D software for the experimental class was based on indicators of problem solving measurements and the use of conventional models in the control class. Meanwhile, the purpose of data collection using documentation techniques is as supporting data in the implementation of this research.

\section{Research Procedure}

The implementation procedure in this study includes several main stages, namely the planning stage, the implementation stage and the reporting stage. 
1) The planning stage, is the first step in carrying out this research action which includes the stages of problem identification, formulation of the problem to be studied, research objectives, assessment of related theories, and consideration of the methods used. In addition, in the planning stage, the stage of making research instruments related to predetermined problem-solving indicators is also carried out, then after the instrument is finished, a limited trial stage is carried out in the form of testing the validity and homogeneity of the instrument to make prerequisites for the use of research instruments at the implementation stage.

2) Implementation stage, this second stage is the core stage in research, namely giving pretest to students to determine the initial capability of students' ability to solve mathematical problems, then conducting experimental actions that have been determined by the control class and experimental class and the next stage in the form of giving posttest to determine student learning outcomes after different treatments.

3) The reporting stage is the final stage in the form of data recapitulation activities, data testing, to drawing conclusions based on the objectives to be achieved, namely knowing the effect of using a problem based instruction model using Cabri 3D software to solve problems. The complete procedure for carrying out the research has been presented in Figure 1.

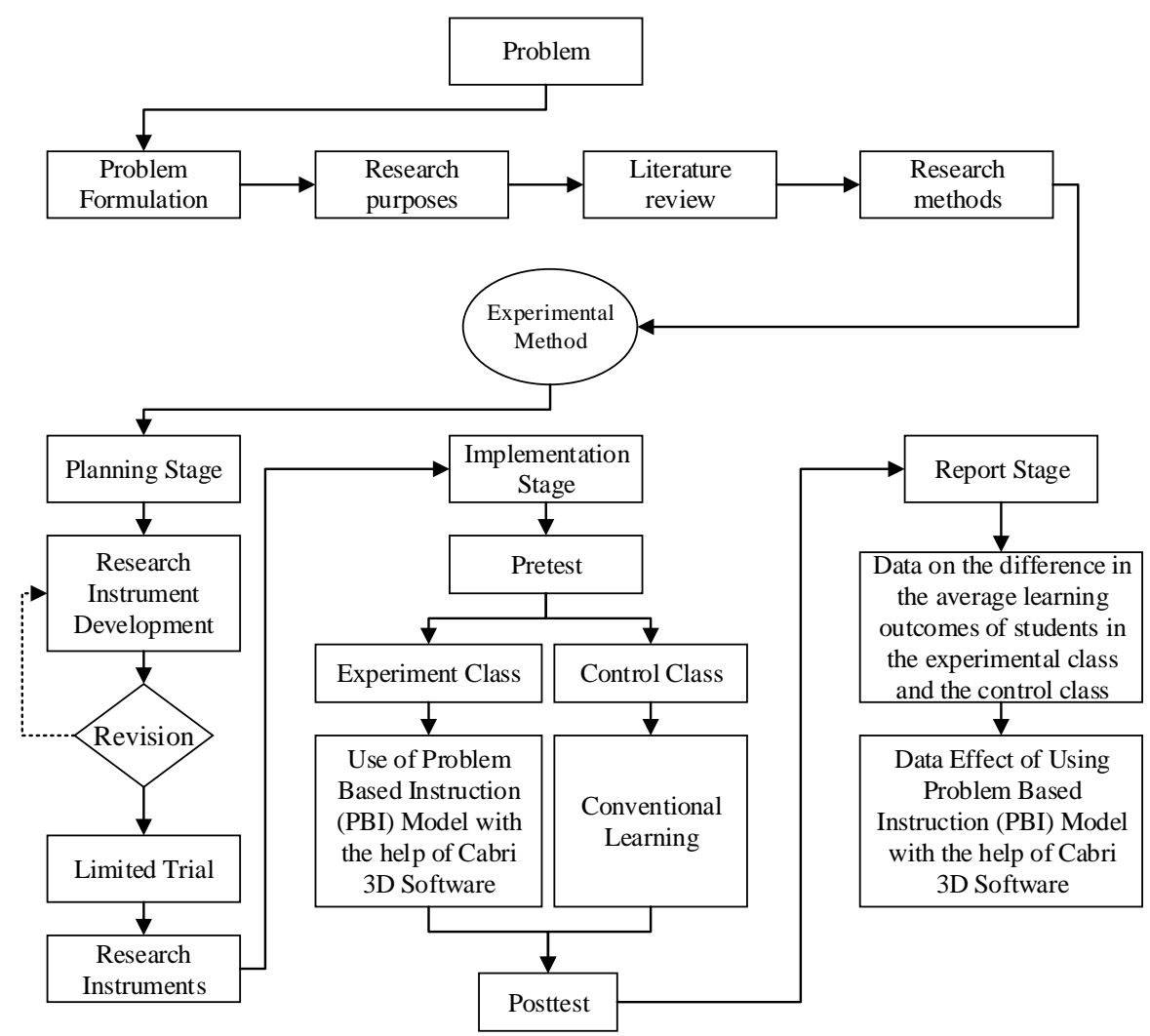

Figure 1. Research Implementation Procedure

Source: Author (2021) 
DOI: https://doi.org/10.24127/ajpm.v10i4.4096

\section{Instrument Development}

The instrument used in the implementation of this research is to use a test. The test used is a test in the form of descriptions. The description test is a type of learning ability test that requires answers that are discussion or descriptions of words. The use of the test instrument aims to find out whether there is a problem based instruction model using Cabri 3D software to solve mathematical problems in MTs. Muhammadiyah 8 Siabu. The researcher used a test instrument in the form of an essay. The instrument test consists of 5 questions with the achievement of indicators of ability in solving problems presented in Table 2 .

Table 2. The Development of Problem Solving Ability Test Instruments

\begin{tabular}{|c|c|c|c|c|c|}
\hline & $\begin{array}{l}\text { Indicator } \\
\text { Variable }\end{array}$ & Indicator test & & Measurement Question Items & Items \\
\hline \multirow[t]{4}{*}{$\begin{array}{l}\text { 1) } \\
\text { 2) } \\
\text { 3) } \\
\text { 4) }\end{array}$} & $\begin{array}{l}\text { Understanding } \\
\text { the problem } \\
\text { Make a plan } \\
\text { Do the plan } \\
\text { Check the }\end{array}$ & $\begin{array}{c}\text { Determine } \\
\text { surface area } \\
\text { ball if the } \\
\text { other } \\
\text { is known }\end{array}$ & 2) & $\begin{array}{l}\text { A ball with a radius of } 30 \mathrm{~cm} \text {, what is the surface } \\
\text { area of the ball? } \\
\text { A ball has a volume of } 36 \mathrm{~cm} 3 \text {, what is the } \\
\text { surface area of the ball? }\end{array}$ & 1,2 \\
\hline & $\begin{array}{l}\text { correctness of } \\
\text { the answer }\end{array}$ & $\begin{array}{l}\text { Determine } \\
\text { ball volume }\end{array}$ & 3) & $\begin{array}{l}\text { The radius of a ball is } 21 \mathrm{~cm} \text {, what is the volume } \\
\text { of the ball? } \\
\text { Class XII IPS-1 held a practice of the } \\
\text { geographical location of the world in a globe } \\
\text { (globe), Rahmad one of the group leaders wanted } \\
\text { to measure the surface area of a globe with a } \\
\text { diameter of } 45 \mathrm{~cm} \text {. What is the surface area of } \\
\text { the globe? }\end{array}$ & 3,4 \\
\hline & & & & $45 \mathrm{~cm}$ & \\
\hline & & $\begin{array}{l}\text { Determine } \\
\quad \text { large } \\
\text { surface and } \\
\text { ball volume }\end{array}$ & 5) & $\begin{array}{l}\text { 5) If a ball has a radius of } 30 \mathrm{~cm} \text {, what is: } \\
\text { a) Volume of the ball? } \\
\text { b) Surface area of the sphere? } \\
\text { c) Surface area of the sphere? } \\
\text { The following picture is a child playing soccer. } \\
\text { The ball has a diameter of } 392 \mathrm{~cm} 2 \text {. After so } \\
\text { many times he kicked the ball, finally the ball } \\
\text { leaked. What volume of air must the child fill? }\end{array}$ & 5,6 \\
\hline
\end{tabular}

Source: Plan of Rearch (2021)

\section{Data analysis technique}

The data analysis technique used is inferential statistics in the form of a ttest which aims to determine the difference in the average value of learning outcomes with the experimental class and control class and to determine the significance value of the test effect of using a problem based instruction model using Cabri 3D software to solve mathematical problems. Meanwhile, the scoring stage used to determine the average difference and test the effect of the use of the model used has been presented in Table 3. 
DOI: https://doi.org/10.24127/ajpm.v10i4.4096

Table 3. Scoring of Research Data Analysis

\begin{tabular}{|c|c|c|c|}
\hline No & Indicator & Sub Indicator & Score \\
\hline \multirow{4}{*}{1} & \multirow{4}{*}{$\begin{array}{l}\text { Understand } \\
\text { problem }\end{array}$} & Don't give an answer & 0 \\
\hline & & Write down what is known or asked & 1 \\
\hline & & Write but not correct & 2 \\
\hline & & Writing known, correctly asked & 3 \\
\hline \multirow{3}{*}{2} & \multirow{3}{*}{ Plan Solution } & Don't design a solution & 0 \\
\hline & & Designing a solution but it's not quite right & 1 \\
\hline & & Designing a solution properly & 2 \\
\hline \multirow{4}{*}{3} & \multirow{4}{*}{ Doing plan } & There is no answer at all & 0 \\
\hline & & Completed the draft but most of the answers are wrong & 1 \\
\hline & & Solving the problem but mostly correct & 2 \\
\hline & & Complete the draft with complete answers correctly & 3 \\
\hline \multirow{3}{*}{4} & \multirow{3}{*}{ Check again } & Don't write a conclusion & 0 \\
\hline & & Making conclusions but not right & 1 \\
\hline & & Make the right conclusions & 2 \\
\hline
\end{tabular}

Source: Hendriana \& Utari (2014)

\section{RESULT AND DISCUSSION}

\section{1) Description of Research Data}

The primary data in this study were in the form of the results of the pretest and posttest in the experimental class and the control class that were carried out during the follow-up research in the field, the following is a description of the primary data obtained, namely as Table 4.

Table 4. Pre Test Results of Students' Problem Solving (Experiment class and Control Class)

\begin{tabular}{|c|c|c|c|c|c|c|}
\hline \multirow{2}{*}{ Category } & \multirow{2}{*}{ Score } & \multirow{2}{*}{ Clasification } & \multicolumn{2}{|c|}{ Frequency } & \multicolumn{2}{|c|}{ Percentage (\%) } \\
\hline & & & Experiment & Control & Experiment & Control \\
\hline A & $100-90$ & Very Good & 0 & 0 & 0,00 & 0,00 \\
\hline B & $89-80$ & Well & 4 & 0 & 18,00 & 0,00 \\
\hline $\mathrm{C}$ & $79-65$ & Enough & 2 & 10 & 8,00 & 40,00 \\
\hline $\mathrm{D}$ & $64-55$ & Less & 7 & 7 & 30,00 & 28,00 \\
\hline $\mathrm{E}$ & $54-0$ & Very Less & 10 & 8 & 44,00 & 32,00 \\
\hline \multicolumn{3}{|c|}{ Total } & 23 & 25 & 100,00 & 100,00 \\
\hline \multicolumn{7}{|c|}{ Mean Pre Test $($ Experiement $)=57,65$} \\
\hline \multicolumn{7}{|c|}{ Mean Pre Test (Control) $=60,65$} \\
\hline
\end{tabular}

Source: Research Results Data (2020)

Based on Table 4 shows that the pretest results obtained in the control class explain that problem solving on the subject matter of building space with the number of samples $=25$, obtained the total value $=1514$ with the highest value being 80 and the lowest value being 46. From the SPSS v.21 calculation. The pretest value of problem solving ability in the control class was obtained with an average value of 60.56 . From these results, it can be concluded that the problemsolving ability in the control class can be categorized as low. Meanwhile, the results of the experimental class problem solving pretest explained that solving problems on the subject matter of building space with a sample size $=$ 23 , obtained the total value $=1326$ with 
the highest value being 82 and the lowest value being 40. From the SPSS v.21 calculation, the pretest value was obtained. problem solving ability in the Experiment class with an average value of 57.65. from these results it can be concluded that the problem-solving ability in the class Experiments can be categorized as low. Meanwhile, the posttest results in the field after the experimental class treatment was carried out using the Problem Based Instruction model through the help of Cabri 3D software were juxtaposed with the control class that did not use the Problem Based Instruction model through the help of Cabri 3D software, for more details, it is presented in Table 5 .

Table 5. Post Test Results of Students' Problem Solving

\begin{tabular}{|c|c|c|c|c|c|c|}
\hline \multirow{2}{*}{ Category } & \multirow{2}{*}{ Score } & \multirow{2}{*}{ Clasification } & \multicolumn{2}{|c|}{ Frequency } & \multicolumn{2}{|c|}{ Percentage (\%) } \\
\hline & & & Experiment & Control & Experiment & Control \\
\hline A & $100-90$ & Very Good & 0 & 0 & 0,00 & 0,00 \\
\hline B & $89-80$ & Well & 5 & 4 & 22,00 & 16,00 \\
\hline $\mathrm{C}$ & $79-65$ & Enough & 11 & 13 & 48,00 & 52,00 \\
\hline $\mathrm{D}$ & $64-55$ & Less & 7 & 8 & 30,00 & 32,00 \\
\hline \multirow[t]{4}{*}{$\mathrm{E}$} & $54-0$ & Very Less & 0 & 0 & 0,00 & 0,00 \\
\hline & \multicolumn{2}{|c|}{ Total } & 23 & 25 & 100,00 & 100,00 \\
\hline & \multicolumn{4}{|c|}{ Mean Post Test $($ Experiement $)=75,47$} & & \\
\hline & \multicolumn{4}{|c|}{ Mean Post Test $($ Control $)=68,32$} & & \\
\hline
\end{tabular}

Source: Research Results Data (2020)

Based on Table 5 shows that the results of the posttest data obtained on problem-solving abilities on the subject of building space in the control class explain that problem solving on the subject matter of building space with the number of samples $=25$, obtained the total value $=1708$ with the highest value being 82 and the lowest value of 60. From the calculation of SPSS v.21, the posttest value of the problemsolving ability in the control class was obtained with an average value of 68.32. from these results it can be concluded that the problem-solving ability in the control class can be categorized as moderate. Meanwhile, the results of the posttest data obtained on the problem-solving ability on the subject of building space in the Experiment class explained that problem solving on the subject matter of building blocks with the number of samples $=23$, obtained the total value $=$
1638 with the highest value being 88 and the lowest value being 58. From SPSS v.21 calculation obtained the posttest value of problem solving ability in the Experiment class with an average value of 75.47. From these results, it can be concluded that the problem solving ability in the Experiment class can be categorized as good.

\section{2) Description of Statistical Test Data}

Recording the perception of primary data in the form of pretest and posttest on the results of the research that has been carried out, so when juxtaposed the two data can be drawn a common thread that there is a good influence in the mathematics learning process to improve students' ability to solve problems during the learning process. The data is also reinforced by the score of the test results that have been presented in Table 6 . 
DOI: https://doi.org/10.24127/ajpm.v10i4.4096

Table 6. Hypothesis Testing Results Data

Independent Sample Test

Students' Problem Solving

\begin{tabular}{l|c}
\hline Sig.(2-tailed) & 0,0345 \\
\hline N Experiment & 23 \\
\hline N Control & 25 \\
\hline N-gain Experiment & 75,47 \\
\hline Mean Control & 68,32 \\
\hline$S_{1}^{2}$ Experiment & 96,63 \\
\hline$S_{1}^{2}$ Control & 71,89 \\
\hline Nilai $\mathrm{t}_{\text {hitung }}$ & 2,708 \\
\hline Nilai $\mathrm{t}_{\text {table }}$ & 2,012 \\
\hline
\end{tabular}

Source: Research Data Processing (2020)

In this study, there were two classes that became the research sample, namely class VIII-A as an experimental class using a problem based instruction model assisted by 3D cabri software, and class VIII-B as a control class using the lecture method (direct teachercentered learning without give good feedback). The two classes were each given a pretest to see the students' initial ability in problem solving, after doing the test the results of the two classes were normally distributed but still relatively low. The experimental class was given treatment using a Problem Based Instruction model with the help of Cabri 3D software in learning where learning was directed by students to solve problems faced in everyday life. By doing this model in learning will help facilitate students in solving problems.

This is evidenced by the presentation of the data in Table 6 which shows that there is a value of $t$ value $>\mathrm{t}$ table value $(2.708>2.012)$ meaning that $\mathrm{t}$ is in the reception area, so it can be concluded that $\mathrm{Ha}: 12$ or means that the average ability problem solving on the subject of building space using the Problem Based Instruction model assisted by 3D Cabri Software is better than the average problem solving ability on the subject of building space without using the Problem Based Instruction model assisted by 3D Cabri Software. For acceptance, it can be concluded that there is an effect of the Problem Based Instruction model with the help of 3D Cabri Software on problem-solving abilities on the subject in class VIII.

The results of the data analysis tests carried out, the results of this study are supported by the results of previous studies, Margana (2016) released the results of his research which showed that there was an effect of the Problem Based Instruction model on problem solving abilities. However, in this study only describes the attitudes of students who are more prominent in accepting Problem Based Instruction learning than mastering the concept of learning the Problem Based Instruction model in relation to students' problem solving abilities. In line with Tama et al.,(2020) who prove in their research that there is an effect of using Cabri 3D software on student learning outcomes and motivation. However, this study did not involve students in problem solving abilities, the study only showed students' work as a result of student learning and motivation. Meanwhile, Ayyildiz \& Tarhan, (2018) released that there was an effect of the Problem 
Based Instruction model on student learning outcomes.

Rianjanu et al., (2020) added in a research that PBL can improve problem-solving skills with the steps: (1) orienting students to the problem classically; (2) organizing students to study in a group work of four people and the division of tasks for each member; (3) guiding individual and group investigations on the same topic, discussed maximum in two groups; (4) developing and presenting the work done in front of the class with more time allocation in the discussion session; (5) analyzing and evaluating the problem-solving process that focuses on re-checking the results.

Meanwhile, Anam et al., (2020) also suggested from the results of his research which showed that the use of the PBL model could improve communication and problem-solving skills in learning mathematics at the elementary level. However, the effect is not that great. Future research can use learning media or other models, such as inquiry, discovery, and project-based learning in improving math learning skills. Based on the results of the research above, it is confirmed that the state of art in this study is to use learning media in the form of 3D Cabri to determine students' skills in solving mathematical problems.

Bearing in mind, the advantages of using 3D technology in education can be noted as follows Martín-Gutiérrez et al., (2017) including: (1) Teachers teach with the help of high-tech educational tools, thereby saving time in explaining complex concepts and processes; (2) Visualization of "complicated" themes in the curriculum helps students better understand the material being studied; Incorporating 3D models of processes and objects in a traditional way of learning introduces innovation into "routine" learning processes, increasing motivation to learn (Getso \& Bakon, 2017); (4) attracting students' attention to the lesson, increasing concentration and attention, increasing and accelerating the perception of the material being studied; (5) Facilitating the systematization of knowledge; and (6) It facilitates the learning of more information, which has a positive effect on test and exam results.

And what needs to be understood in addition to the use of learning media which is a supporting tool in the current industrial era, is the packaging of skills in the teaching and learning process, such as problem solving skills in research that has been carried out. This is because considering that problem solving skills are part of the 21st century skills that educators must provide to their students in order to adapt to changing times. As stated by (Getzels \& Csikszentmihalyi, 2017) that problem solving is a process where a person feels a problem to find a solution for himself. Problem solving skills are also the most important requirement of the 21 st century. Problem solvingbased learning is learning that can develop students' thinking processes by providing problems to be researched individually or in groups to find solutions to these problems.

Some researchers also argue that problem solving ability itself is one of the basic skills needed in all areas of life. Problem solving skills are one of the basic skills needed in all areas of life. Problem solving skills are an integral part of human growth. Humans start their problems and problem solving efforts from an early age. These skills are acquired with the help and orientation of the family and 
environment before school, and they are acquired systematically with school life and continue for a lifelong process (Bagiati \& Evangelou, 2016; Bers, 2020; Dörner \& Funke, 2017)

\section{CONCLUSION AND SUGGESTION}

Learning in the $21 \mathrm{st}$ century essentially requires teachers to pack an act of learning that utilizes existing technology, teachers should have skills in terms of technology and pedagogy, this aims to balance the changing times and improve the quality of learning in order to create good quality human resources. . One form of technology and pedagogical integration is the use of the Problem Based Instruction model with the help of 3D Cabri Software which is an act of treatment that can give a positive influence in the mathematics learning process in the classroom.

This is evidenced by the follow-up research conducted which revealed that there was a significant effect of the Problem Based Instruction model assisted by 3D Cabri Software on students' problem solving abilities on the subject of building space. The results of this research are motivated by the existence of research procedurals that are very careful in carrying out research so that they also get effective results, especially when students are given treatment by using Cabri 3D software to solve mathematical problems that have been presented in the form of tests.

The advantages in this study further increase the relevance of research results in the field of mathematics education, especially in solving mathematical problems. Meanwhile, the lack of research only focuses on the subject of the ball, the use of Cabri 3D Software is still difficult in authentic investigations (characteristics of the
Problem Based Instruction model) a problem of making and displaying balls in a predetermined size (area and volume) as well as on Cabri 3D Software. it can't display half ball. The implication of this research is that the results and research tools can be taken into consideration for applying the Problem Based Instruction learning model assisted by 3D cabri software to other building materials and other software developments to improve the quality of mathematics learning in the classroom considering the demands of the 4.0 revolution era society 5.0 educators who are competent in using technology.

Meanwhile, the suggestions submitted, especially to further researchers, are the need for problem solving research, especially in learning mathematics to use other software assistance in supporting innovative and creative learning in order to improve students' problem solving abilities in class so that it can also increase the relevance of research in the field of mathematics education and education. as a reference for creating effective, efficient and innovative learning.

\section{REFERENCES}

Adelabu, F. M., Makgato, M., \& Ramaligela, M. S. (2019). The importance of dynamic geometry computer software on learners' performance in geometry. Electronic Journal of E-Learning.

Akpinar, Ö. (2020). The Effect of Empathy Levels of Female School of Physical Education and Sports Students on Problem Solving Skill Levels. Asian Journal of Education and Training. https://doi.org/10.20448/journal.52 2.2020.63.406.411 
Al-Mutawah, M. A., Thomas, R., Eid, A., Mahmoud, E. Y., \& Fateel, M. J. (2019). Conceptual understanding, procedural knowledge and problem-solving skills in mathematics: High school graduates work analysis and standpoints. International Journal of Education and Practice. https://doi.org/10.18488/journal.61 .2019.73.258.273

Alrahlah, A. (2016). How effective the problem-based learning (PBL) in dental education. A critical review. In Saudi Dental Journal. https://doi.org/10.1016/j.sdentj.201 6.08.003

Amiluddin, R., \& Sugiman, S. (2016). Pengaruh Problem Posing Dan Pbl Terhadap Prestasi Belajar, dan Motivasi Belajar Mahasiswa Pendidikan Matematika. Jurnal Riset Pendidikan Matematika. https://doi.org/10.21831/jrpm.v3i1. 7303

Anam, K., Sudarwo, R., \& Wiradharma, G. (2020). Application of the Problem Based Learning Model to Communication Skills and Mathematical Problem Solving Skills in Junior High School Students. JTAM (Jurnal Teori Dan Aplikasi Matematika). https://doi.org/10.31764/jtam.v4i2. 2553

Ayyildiz, Y., \& Tarhan, L. (2018). Problem-based learning in teaching chemistry: enthalpy changes in systems. Research in Science and Technological Education. https://doi.org/10.1080/02635143.2 017.1366898

Bagiati, A., \& Evangelou, D. (2016). Practicing engineering while building with blocks: identifying engineering thinking. European Early Childhood Education
Research

Journal. https://doi.org/10.1080/1350293X. 2015.1120521

Bao, L., Xiao, Y., Koenig, K., \& Han, J. (2018). Validity evaluation of the Lawson classroom test of scientific reasoning. Physical Review Physics Education Research. https://doi.org/10.1103/PhysRevPh ysEducRes.14.020106

Bers, M. U. (2020). Coding as a playground: Programming and computational thinking in the early childhood classroom. In Coding as a Playground: Programming and Computational Thinking in the Early Childhood Classroom. https://doi.org/10.4324/978100302 2602

Carpenter, T. P., \& Moser, J. M. (2020). The development of addition and subtraction problem-solving skills. In Addition and Subtraction: A Cognitive Perspective. https://doi.org/10.4324/978100304 6585-2

De Vita, M., Verschaffel, L., \& Elen, J. (2018). Towards a better understanding of the potential of interactive whiteboards in stimulating mathematics learning. Learning Environments Research. https://doi.org/10.1007/s10984017-9241-1

Dörner, D., \& Funke, J. (2017). Complex problem solving: What it is and what it is not. Frontiers in Psychology.

https://doi.org/10.3389/fpsyg.2017. 01153

Fitra, R., Hajidin, \& Anshari, B. . (2016). Peningkatan Kemampuan Pemecahan Masalah Matematis Siswa Smk Melalui Model. Didaktik Matematika.

Getzels, J. W., \& Csikszentmihalyi, M. (2017). From problem solving to 
DOI: https://doi.org/10.24127/ajpm.v10i4.4096

problem finding. In Perspectives in Creativity.

https://doi.org/10.4324/978131512 6265-4

Halim, A., Susanna, Evendi, Yusrizal, Musdar, \& Irwandi, I. (2021). The impact of the problem-based instruction model on the students' problem solving ability. AIP Conference Proceedings. https://doi.org/10.1063/5.0043124

Ibrahim, M. Y., Yusof, M. R., Yaakob, M. F. M., \& Othman, Z. (2019). Communication skills: Top priority of teaching competency. International Journal of Learning, Teaching and Educational Research. https://doi.org/10.26803/ijlter.18.8. 2

Kirkley, J. (1998). Principles for Teaching Problem Solving: Technical Paper \#4. PLATO Learning.

Kozikoğlu, İ. (2019). Investigating critical thinking in prospective teachers: Metacognitive skills, problem solving skills and academic self-efficacy. Journal of Social Studies Education Research.

Lebamovski, P., \& Gospodinov, M. (2019). 3D INNOVATION TECHNOLOGIES IN EDUCATION. CBU International Conference Proceedings. https://doi.org/10.12955/cbup.v7.1 405

Lise öğrencilerinin problem çözme becerileri. (2002). Hacettepe Egitim Dergisi.

Maharani, A., \& Laelasari, L. (2017). Experimentation Of Spices Learning Strategies With The Method Of Problem Based Learning (Pbl) To Build Motivation And The Ability To Think Logically For Vocational
School Students. Infinity Journal. https://doi.org/10.22460/infinity.v6 i2.p149-156

Mammana, M. F. (2019). The Modernity of the Meraner Lehrplan for Teaching Geometry Today in Grades 10-11: Exploiting the Power of Dynamic Geometry Systems.

https://doi.org/10.1007/978-3-31999386-7_11

Marnita, Taufiq, M., Iskandar, \& Rahmi. (2020). The effect of blended learning problem-based instruction model on students' critical thinking ability in thermodynamic course. Jurnal Pendidikan IPA Indonesia. https://doi.org/10.15294/jpii.v9i3.2 3144

Martín-Gutiérrez, J., Mora, C. E., Añorbe-Díaz, B., \& GonzálezMarrero, A. (2017). Virtual technologies trends in education. Eurasia Journal of Mathematics, Science and Technology Education.

https://doi.org/10.12973/eurasia.20 $17.00626 \mathrm{a}$

Muah, T. (2016). Penggunaan Model Pembelajaran Problem Based Instruction (PBI) Untuk Meningkatkan Keaktifan dan Hasil Belajar Matematika Siswa Kelas 9b Semester Gasal Tahun Pelajaran 2014/2015 SMP NEGERI 2 TUNTANG - SEMARANG. Scholaria : Jurnal Pendidikan Dan Kebudayaan.

https://doi.org/10.24246/j.scholaria .2016.v6.i1.p41-53

Nariman, N., \& Chrispeels, J. (2016). PBL in the Era of Reform Standards: Challenges and Benefits Perceived by Teachers in One Elementary School The Interdisciplinary Journal of 
DOI: https://doi.org/10.24127/ajpm.v10i4.4096

Problem-based Learning. Interdisciplinary Journal of Problem-Based Learning.

Novianti, N. K. D., Santoso, H., \& Lepiyanto, A. (2020). Pengaruh Penggunaan Model Pembelajaran Problem Based Instruction (Pbi) Terhadap Hasil Belajar Peserta Didik Dalam Pembelajaran Biologi. BIOEDUKASI (Jurnal Pendidikan Biologi). https://doi.org/10.24127/bioedukas i.v11i2.3427

Nurjanah, Latif, B., Yuliardi, R., \& Tamur, M. (2020). Computerassisted learning using the Cabri 3D for improving spatial ability and self- regulated learning. Heliyon.

https://doi.org/10.1016/j.heliyon.20 20.e 05536

Orzechowski, J., Kruchowska, E., Gruszka, A., \& Szymura, B. (2017). Understanding factors behind the effectiveness of personal identification: Revolution - a new technique of creative problem solving. Thinking Skills and Creativity. https://doi.org/10.1016/j.tsc.2016.1 2.004

Özgenel, M. (2018). Modeling the relationships between school administrators' creative and critical thinking dispositions with decision making styles and problem solving skills. Kuram ve Uygulamada Egitim Bilimleri. https://doi.org/10.12738/estp.2018. 3.0068

Rahma, A. (2019). Pengaruh penggunaan model pembelajaran Problem Based Instruction (PBI) terhadap kemampuan pemecahan masalah matematika materi teorema Pythagoras di .... JURNAL MathEdu (Mathematic
Education Journal).

Rianjanu, A., Julian, T., Hidayat, S. N., Yulianto, N., Majid, N., Syamsu, I., Wasisto, H. S., \& Triyana, K. (2020). Quartz crystal microbalance humidity sensors integrated with hydrophilic polyethyleneimine-grafted

polyacrylonitrile nanofibers. Sensors and Actuators, B: Chemical. https://doi.org/10.1016/j.snb.2020. 128286

Sarjoko, S., \& Demitra, D. (2018). Pengembangan Model Pembelajaran Kooperatif Handep Berpasangan Berdasarkan Kaidah Quantum Teaching. Indonesian Journal of Curriculum and Educational Technology Studies. https://doi.org/10.15294/ijcets.v6i1 .22710

Scherer, R., \& Gustafsson, J. E. (2015). The relations among openness, perseverance, and performance in creative problem solving: A substantive-methodological

approach. Thinking Skills and Creativity.

https://doi.org/10.1016/j.tsc.2015.0 4.004

Tama, B. J., Rezeki, S., \& Hikmah, R. (2020). Kemampuan Pemahaman Matematis Siswa dengan Menggunakan Cabri 3D. Journal of Instructional Mathematics. https://doi.org/10.37640/jim.v1i1.2 65

Tösten, R., Han, B., \& Anik, S. (2017). The Impact of Parental Attitudes on Problem Solving Skills in High School Students. Universal Journal of Educational Research. https://doi.org/10.13189/ujer.2017. 050121

Vallo, D., \& Zahorska, J. (2017). Geometry software cabri 3D in 
DOI: https://doi.org/10.24127/ajpm.v10i4.4096

teaching stereometry. Application of Information and Communication Technologies, AICT 2016 Conference Proceedings. https://doi.org/10.1109/ICAICT.20 16.7991805

YAVUZ, E., \& ATAR, H. Y. (2020). An Examination of Turkish Students' PISA 2015 Collaborative Problem-Solving Competencies. International Journal of Assessment Tools in Education. https://doi.org/10.21449/ijate.6821 03

YAZGAN, A. D. (2021). Investigation of the Relationship Between Preservice Teachers' Lateral Thinking Levels and Problem Solving Skills. Kuramsal Eğitimbilim. https://doi.org/10.30831/akukeg.79 3247

Yuberti, Latifah, S., Anugrah, A., Saregar, A., Misbah, \& Jermsittiparsert, K. (2019). Approaching problem-solving skills of momentum and impulse phenomena using context and problem-based learning. European Journal of Educational Research. https://doi.org/10.12973/eujer.8.4.1217

Yuliardi, R., Mahpudin, A., \& Rosyid, A. (2021). Implementation of Mathematics Learning-Assisted Cabri 3D Software to Improve Spatial Ability of High School Students on Three Dimensional Geometry. Journal of Physics: Conference Series. https://doi.org/10.1088/17426596/1764/1/012042

Yuliati, L., Riantoni, C., \& Mufti, N. (2018). Problem solving skills on direct current electricity through inquiry-based learning with $\mathrm{PhET}$ simulations. International Journal of

Instruction. https://doi.org/10.12973/iji.2018.1 $149 \mathrm{a}$

Zulkardi, Meryansumayeka, Putri, R. I. I., Alwi, Z., Nusantara, D. S., Ambarita, S. M., Maharani, Y., \& Puspitasari, L. (2020). How students work with pisa-like mathematical tasks using covid-19 context. Journal on Mathematics Education.

https://doi.org/10.22342/jme.11.3.1 2915.405-416 